\title{
Primjena broja somatskih stanica za dijagnostiku mastitisa i utjecaj na kakvoću mlijeka
}

\author{
K. Knežević, V. Dobranić, D. Đuričić, M. Samardžija, M. Benić, I. Getz*, \\ M. Efendić, L. Cvetnić, J. Šavorić, I. Butković, M. Cvetnić, M. Mazić i N. Maćešić
}

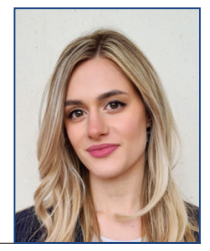

\section{Sažetak}

Mastitis je upalna reakcija organizma na infekciju sekretornog dijela mliječne žlijezde. Uzročnici mastitisa dijele se bojanjem po Gramu na Gram-pozitivne i Gramnegativne; prema etiologiji na kontagiozne i uvjetovane uzročnike. Kontagiozni se uzročnici najčešće prenose tijekom mužnje i prouzroče dugotrajne, kronične mastitise, uglavnom subkliničkog tijeka. Za razliku od njih, uvjetovani uzročnici $u$ pravilu izazivaju kratkotrajne infekcije, ali s češćim kliničkim manifestacijama. Inficirane se krave otkrivaju dijagnostikom mastitisa, koja se najčešće provodi neizravnim ili izravnim metodama određivanja broja somatskih stanica i bakteriološkom pretragom mlijeka. Zagrebački mastitis test je brza i jednostavna orijentacijska metoda $\mathrm{u}$ procjeni broja somatskih stanica koji se provodi u terenskim uvjetima. Somatske stanice čine epitelne stanice i leukociti. Nalaze se u mlijeku, ali se njihov broj i odnos mijenja ovisno o upalnim promjenama u mliječnoj žlijezdi. Kretanje broja somatskih stanica uglavnom ovisi

o pojavi mastitisa, ali i o stadiju laktacije, životnoj dobi životinje, godišnjem dobu, ali i ostalim bolestima mliječne krave. Mlijeko s povećanim brojem somatskih stanica ima promijenjenu kakvoću. Mlijeko sadrži niži udio mliječne masti i laktoze, a povećan je i udio proteina i električna provodljivost zbog povišene koncentracija klora i natrija u mlijeku. Osim toga, mlijeko ima i smanjenu termostabilnost te mu je smanjena sposobnost podsiravanja i formiranja gruša. Takvo mlijeko ima užegli okus i nije pogodno za proizvodnju kondenziranog mlijeka, mlijeka u prahu i steriliziranog mlijeka. Rok trajanja sireva proizvedenih od takvog mlijeka zbog zadržavanja veće količine vode je smanjen. Pravilnim i redovitim provođenjem postupaka dezinfekcije sisa vimena prije i poslije mužnje poboljšava se prinos i kakvoća mlijeka, odnosno smanjuju se troškovi liječenja mastitisa, a povećava se i prihod farme.

Ključne riječi: mastitis, somatske stanice, mlijeko, kakvoća mlijeka

Klara KNEŽEVIĆ, dr. med. vet., Biognost, Zagreb, Hrvatska; dr. sc. Vesna DOBRANIĆ, dr. med. vet., redovita profesorica, dr. sc. Marko SAMARDZZIJA, dr. med. vet., redoviti profesor, Iva GETZ*, dr. med. vet., izvanredna profesorica, (Dopisni autor, e-mail: igetz@vef.hr), Maša EFENDIĆ, dr. med. vet., Juraj ŠAVORIĆ, dr. med. vet., asistent, Ivan BUTKOVIĆ, dr. med. vet., asistent, Marija CVETNIĆ, dr. med. vet., asistentica, dr. sc. Nino MAĆEŠIĆ, dr. med. vet., izvanredni profesor, Veterinarski fakultet Sveučilišta u Zagrebu, Hrvatska; dr. sc. Dražen ĐURIČIĆ, dr. med. vet., docent, Mount-trade, Garešnica, Hrvatska; dr. sc. Miroslav BENIĆ, dr. med. vet., docent, dr. sc. Luka CVETNIĆ, Hrvatski veterinarski institut, Zagreb, Hrvatska; Marin MAZIĆ, Veterinarska Ambulanta Marković, Zagreb, Hrvatska 


\section{Uvod}

Mlijeko pripada skupininezamjenjivih namirnica za mlade sisavce jer je ono prva hrana koja potom postaje važna namirnica tijekom cijelog života. Mlijeko je sekret mliječne žlijezde, a stvara se iz specifičnih sastojaka koje prelaze iz krvi u mliječnu žlijezdu. Kroz krvožilni sustav vimena mora procirkulirati $500 \mathrm{~L}$ krvi za proizvodnju jedne litre mlijeka (Bačić, 2009.). Mliječna žlijezda osigurava prehranu mladunčadi, ali krave danas daju i mnogo više mlijeka nego što mladunče može konzumirati.

Znatno povećanje mliječnosti utječe na porast stresa mliječnih krava, što može uvjetovati razvoju mastitisa. Mastitis je upalna reakcija organizma, a uzrokuju ga brojni patogeni agensi koji ulaze kroz sisni kanal i umnažaju se u sisnoj cisterni. Neki od najvažnijih uzročnika mastitisa su: Staphylococcus aureus, Streptococcus uberis, Mycoplasma spp. i Escherichia coli (Calvinho i Tirante, 2005., Gračner i sur., 2006., Maćešić i sur., 2012., Carrillo-Casas i Morales, 2012.). Identifikacija uzročnika mastitisa važna je kako bi se poduzele potrebne mjere koje bi smanjile rizik od širenja bolesti i pojave kroničnih oblika te provelo ciljano liječenje. Broj somatskih stanica (BSS) u mlijeku desetljećima se koristi kao praktičan i jednostavan način ustvrđivanja mastitisa. Mliječna se žlijezda smatra zdravom ukoliko je BSS manji od 200 000/mL; BSS se koristi i kao važan parametar kakvoće mlijeka, a povećava se zbog povećane propusnosti krvnih žila vimena te prelaska iona, proteina $\mathrm{i}$ upalnih stanica $\mathrm{u}$ mlijeko (Dillon, 2012.).

Mastitis utječe na dobrobit životinja i sigurnost hrane, ali može prouzročiti i najveće ekonomske gubitke u modernom mliječnom govedarstvu. Ekonomski gubitci očituju se kroz smanjenu mliječnost, vrijednost odbačenog mlijeka, smanjenu plodnost te troškove liječenja i veterinara. Svi nabrojeni čimbenici direktno utječu na dohodovnost farme (Bačić, 2009.). Prioritet mliječne industrije je smanjenje mastitisa i proizvodnja visokokvalitetnog mlijeka da bi bili konkurentni na globalnom tržištu (Cvetnić i sur., 2016).

\section{Mliječna žlijezda}

Mliječna žlijezda ili vime je specijalizirana kožna žlijezda u kojoj se stvara mlijeko. Sastoji se od četiri odvojene sekretorne žlijezde ili četvrti. Suspenzorni ligament dijeli vime na lijevu i desnu polovicu, a fibrozna opna na prednju i stražnju. Mlijeko i mikroorganizmi ne mogu prelaziti iz jedne četvrti u drugu pa kada je mastitis prisutan $\mathrm{u}$ jednoj četvrti ostale tri četvrti mogu biti zdrave.

Cetvrt se sastoji: od sise, sisne cisterne, žljezdane cisterne, mliječnih kanalića i sekretornog tkiva (Slika 1.). Sekretorno tkivo predstavlja funkcionalni dio mliječne žlijezde koja se sastoji se od velikog broja alveola koje proizvode mlijeko. Mlijeko se putem mliječnih kanalića spušta u žljezdanu i zatim sisnu cisternu, a istječe kroz sisni kanal (Bačić, 2009.). Sisni kanal je i mjesto ulaska mikroorganizama $\mathrm{u}$ vime pa je stoga i prva linija obrane organizma. Dugačak je 8 do $15 \mathrm{~mm}$, a kada je otvoren širok je 0,5 do $2 \mathrm{~mm}$. Mišići sfinktera zatvaraju sisni kanal da bi spriječili ulazak mikroorganizama (Sandholm i sur., 1995., Dillon, 2012.). Širi sisni kanal skraćuje vrijeme potrebno za mužnju, ali predstavlja i povećani rizik od spontanog istjecanja mlijeka i učestalosti mastitisa (Lee i Choudhary, 2006., Tänavots i sur., 2015., Benić i sur., 2018.). Unutrašnjost sisnog kanala obložena je slojevima keratina koji pomaže sisnom kanalu da se zatvori kada mlijeko ne istječe, a keratinski sloj adsorbira mikroorganizme i sprječava njihov ulazak u mliječnu 
cisternu. Tijekom svake mužnje određeni se broj keratinskih stanica, zajedno s mikroorganizmima, odljušti. Tijekom suhostaja keratin se nakuplja i stvara keratinski čep te tako izvana štiti vime od mikroorganizama (Bačić, 2009.).

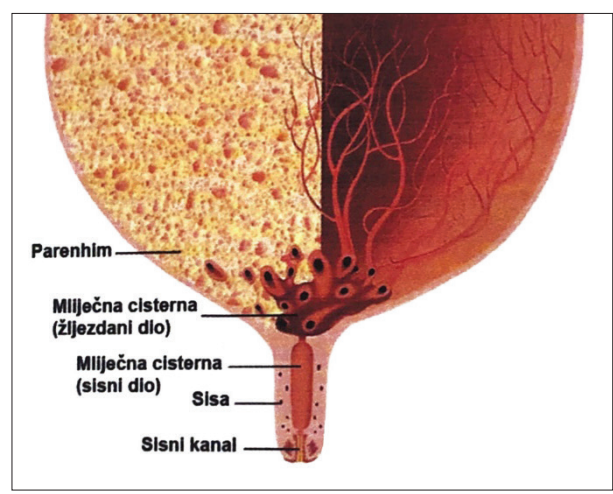

Slika 1. Shematski prikaz građe četvrti (Bačić, 2009.)

\section{Mastitis}

Mastitis je upalna reakcija organizma krava na infekciju sekretornog dijela mliječne žlijezde. Potrebno ga je razlikovati od intramamarne infekcije (IMI) koja ne zahvaća sekretorni dio. Vime krave je u neprekidnom kontaktu $\mathrm{s}$ raznim mikroorganizmima te mnogi čimbenici utječu na to hoće li ili neće doći do mastitisa (Bačić, 2009., Saidi i sur., 2021.). Čimbenici se mogu promatrati na razini četvrti, krave i stada. Ustvrđena je povezanost anatomskog položaja četvrti, oštećenja kože vimena, zdravstvenog stanja sisnog kanala i udaljenosti vrha sise od površine poda s čimbenicima rizika na razini četvrti (Guarín i sur., 2017., Benić i sur., 2018.). Čistoća vimena i sisa smanjuje rizik od infekcije uvjetovanim uzročnicima mastitisa i skraćuje vrijeme čišćenja vimena prije svake mužnje. Vime pravilne građe manje je sklono infekcijama. Visoko i plitko vime ima manji rizik od ozljeda i ostaje čišće te ima dovoljno prostora za ispravno postavljanje muzne jedinice. Dobro izraženi žlijeb koji dijeli vime $u$ dvije jednake polovice, znatno će duže održati četvrti i sise u pravilnoj poziciji tijekom budućih laktacija. Na kratkim, uskim i glatkim sisama vjerojatnost skliznuća muznih čaški je veća, a sise koje završavaju šiljasto sklonije su ozljedama vrška sise.

Strojna se mužnja razlikuje od sisanja teladi, a najčešći problem je mužnja na prazno koja se događa kada stroj za mužnju proizvodi vakuum i pulsira, a mlijeko ne istječe iz mliječne žlijezde ili ako je protok mlijeka tijekom dužeg razdoblja vrlo slab (manje od $1 \mathrm{~L} / \mathrm{min}$ ). Prekomjerna se mužnja uočava pred kraj mužnje, kada je protok mlijeka vrlo slab, a muzni stroj nastavlja s mužnjom. U oba slučaja kao posljedica djelovanja vakuuma, nastaju ozljede sisa koje se očituju crvenilom i oteklinama.

Mala količina keratina normalno oblaže sisni kanal koja se prilikom strojne mužnje uklanja. Kada je nakupljanje keratina pretjerano (hiperkeratosis), završetak sisnog kanala postaje hrapav, na njegovoj površini bakterije se lakše naseljavaju i razmnožavaju i takvu sisu je prije mužnje teže dezinficirati (Bačić, 2009.).

Pojedinačni čimbenici rizika za razvoj mastitisa su: dob, pasmina, stadij laktacije, razina higijene, proizvodnja i broj somatskih stanica u prethodnoj laktaciji. Mastitis se češće razvija u starijih životinja, držanih u prljavom okolišu i onih s višim somatskim stanicama $u$ posljednjoj laktaciji (Hiitiö i sur., 2017., Turk i sur., 2017., Benić i sur., 2018.).

Mastitis prouzroče aerobne i anaerobne bakterije, mikoplazme, kvasci, gljivice, plijesni i alge roda Prototheca. Uzročnici mastitisa podijeljeni su bojanjem po Gramu ili prema etiologiji. Bojanjem po Gramu uzročnici mastitisa dijele se na Gram-pozitivne i Gram-negativne uzročnike. U skupinu Gram-pozitivnih ubrajaju se: stafilokoki, streptokoki i en- 
terokoki. Gram-negativni su: koliformne bakterije, enterokoki, vrste Pseudomonas, Proteus i Serratia spp. Prema etiologiji, odnosno prema izvorima infekcije i načinu širenja mikroorganizama, uzročnike dijelimo na kontagiozne mikroorganizme i uvjetovane ili mikroorganizme iz okoliša. Najčešći kontagiozni uzročnici mastitisa su: Staphylococcus aureus, Streptococcus agalactiae, Mycobacterium bovis i Corynebacterium bovis, a najčešći uvjetovani uzročnici su koliformne bakterije i streptokoki iz okoliša, Streptococcus uberis, Streptococcus dysgalactiae, i Streptococcus bovis (Bačić, 2009.). Staphylococcus aureus je najčešće izolirani uzročnik mastitisa u svijetu. Prevalencija infekcije kreće se od $2 \%$ do preko $50 \%$. Klinička slika oscilira od povećanog broja somatskih stanica kao jedinog pokazatelja infekcije do gangrenoznih i septikemijskih oblika bolesti. S. aureus je vrlo teško iskorijeniti iz stada jer uspješno izbjegava antibiotike nastanjujući se unutar neutrofilnih leukocita i drugih stanica imunološkog sustava te tvorbom mikroapscesa koji sprječavaju mogućnost dolaska antibiotika do bakterija (Benić i sur., 2018.). Mastitis prouzročen bakterijom $S$. aureus prouzroči pad proizvodnje mlijeka od $45 \%$ po zaraženoj četvrti, što je 15 \% po životinji (NMC, 1999., Benić i sur., 2012., Carillo-Casas i Morales, 2012., Cvetnić i sur., 2021.). Do 1960-ih, Streptococcus agalactiae smatran je najznačajnijim uzročnikom mastitisa u krava (Benić i sur., 2018.). S. agalactiae prouzroči zarazni mastitis koji se prenosi izravno s krave na kravu tijekom mužnje te prouzroči iritaciju, edem i subklinički mastitis. Danas je mastitis prouzročen $S$. agalactiae rijedak zbog poboljšanih preventivnih mjera i upravljanja mužnjom te učinkovitim antibiotskim liječenjem (Carillo-Casas i Morales, 2012.).

Najčešći uvjetovani uzročnici mastitisa su: E. coli i $S$. uberis. Ovi uzročnici žive i umnažaju se u fecesu, stelji, vodi, muhama i bilo kojem drugom prikladnom okolišu. Kontrola mastitisa uvjetovanim uzročnicima osniva se na poboljšanju higijene i pravilnoj ventilaciji prostora. Bakterija E. coli može prouzročiti izrazito tešku kliničku sliku s tvrdim i otečenim vimenom. S. uberis nalazi se na slamnatoj stelji, a infekciju izaziva u krava u suhostaju, koju karakterizira iznenadan nastup s povišenom tjelesnom temperaturom (Dillon, 2012.).

Mastitisi su podijeljeni na osnovu kliničke slike, a razlikujuju se dva oblika; subklinički i klinički oblik. Subklinički karakterizira samo blaga upala mliječne žlijezde, a vime i mlijeko izgledaju zdravo. U stadima se javlja češće, a povećani BSS jedini je znak infekcije. Ishod subkliničkog mastitisa je spontano samoizliječenje ili prijelaz u klinički oblik u roku nekoliko sati, dana ili mjeseci (Turk i sur., 2012., Kovačić i sur., 2019. Nedić i sur., 2019.).

Klinički oblik mastitisa ima jasno vidljive simptome. Promjene mogu biti vidljive na vimenu zaražene krave; mlijeko je promijenjene konzistencije $\mathrm{s}$ vidljivim krpičastim ili vlaknastim tvorbama koje čine nakupine odumrlog epitela, leukocita i bjelančevina. Prema jačini simptoma klinički se mastitis dijeli na: blagi, umjereni i teški oblik. Ishodi mogu biti: potpuni oporavak, kronični mastitis, gubitak četvrti, ali i ili smrtni ishod (Bačić, 2009., Burović, 2020.).

Mastitis je najčešći uzrok ekonomskih gubitaka u modernoj mliječnoj industriji. Gubitci se očituju u vidu pada mliječnosti, smanjene kakvoće i higijenske ispravnosti mlijeka, gubitaka premija zbog niže kakvoće mlijeka i niže otkupne cijene. Pad mliječnosti prouzročen je oštećenjem sektretornog dijela vimena koje postaje zamijenjeno ožiljkastim tkivom i neupotrebljivo za daljnje izlučivanje mlijeka.

\section{Somatske stanice}

Mlijeko proizvode epitelne stanice mliječne žlijezde koje su obložene krvnim 
žilama. Iz krvi uzimaju razne prekursore mlijeka te tako sintetiziraju i otpuštaju mlijeko u lumen žlijezde (Alhussien i Dang, 2018.). Somatske stanice čine epitelne stanice i leukociti, tj. neutrofili, makrofagi, limfociti i eritrociti. Epitelne se stanice u mlijeko izlučuju iz žljezdane sluznice, a leukociti kao odgovor na infekciju ili ozljedu ulaze u mliječnu žlijezdu (Sharma i sur., 2011.). Leukociti služe kao obrambeni mehanizam za borbu protiv infekcije i pomoć $u$ oporavku oštećenog tkiva. Najveći porast broja somatskih stanica posljedica je priljeva neutrofila, preko $90 \%$ (Miller i Paape, 1985., Harmon, 1994., Sharma i sur., 2011.). Leukociti u zdravom mlijeku čine približno $25 \%$ somatskih stanica. Funkcija leukovcita je da otkriju i fagocitiraju patogene te pokreću odgovarajući imunološki odgovor. $\mathrm{Na}$ početku infekcije, makrofagi i epitelne stanice mliječne žlijezde sintetiziraju i oslobađaju različite proupalne citokine kao što su: tumor necrosis factor-alpha, interleukin-1 i interleukin-8. Oni induciraju kemotaksiju neutrofila iz okolnih krvnih žila u mliječnu žlijezdu. Limfociti koordiniraju odgovor imunološkog sustava oslobađanjem citokina, dok neutrofili i makrofagi fagocitiraju i uništavaju bakterije (Alhussien i sur., 2015., Alhussien i Dang, 2018.). U slučajevima gdje mehanizam obrane vimena prevlada i eliminira infekciju, BSS će se vratiti na normalne vrijednosti. Međutim, kada upalni odgovor ne uspije eliminirati patogen, leukociti će se kontinuirano izlučivati u mlijeko, što dovodi do povišenog broja somatskih stanica (Dillon, 2012.).

\section{Dijagnostika i monitoring mastitisa}

Dijagnostikom mastitisa otkrivamo inficirane krave i uzročnike koji su izazvali infekciju. Idealan način otkrivanja mastitisa ne postoji, stoga se koriste razne metode koje se prilagođavaju uvjetima na farmi. Metoda dijagnostike mastitisa treba biti jeftina, brza, pouzdana i primjenjiva na farmi. Otkrivanje mastitisa u ranijoj fazi omogućava brže djelovanje i određivanje liječenja (Bačić, 2009.). Dijagnozu kliničkog oblika mastitisa nije teško postaviti, no u slučajevima subkliničkog mastitisa životinje ne pokazuju kliničke znakove i nema uočenih promjena u sastavu mlijeka te je bolest potrebno dijagnosticirati različitim metodama. Subklinički mastitis pogađa oko 25 do 50 \% mliječnih krava pa je ekonomski utjecaj subkliničkog mastitisa znatno veći od utjecaja prouzročenog kliničkim mastitisom (Argaw, 2016., Benić i sur., 2018.). Do danas su za otkrivanje infekcije mliječnih žlijezda razvijene brojne metode.

Za otkrivanje mastitisa važan je pregled vimena koji uključuje inspekciju i palpaciju, no ova je metoda primjenjiva samo za otkrivanje kliničkog oblika mastitisa (Bačić, 2009.). Test električne provodljivosti (ECT) mlijeka temelji se na povećanoj koncentraciji klorida prije pojave kliničkih znakova mastitisa. Roboti za mužnju opremljeni su mjeračima električne provodljivosti, a rezultati se za svaku četvrt mjere i uspoređuju. ECT može pomoći u ranom otkrivanju mastitisa (Dillon, 2012.).

BSS se desetljećima koristi kao zlatni standard u dijagnostici subkliničkog mastitisa. Može se izmjeriti izravnim ili neizravnim metodama. Uzorke mlijeka za mjerenje broja somatskih stanica treba uzeti neposredno prije mužnje, nakon odbacivanja prva tri mlaza mlijeka (Lam i sur., 2009., Dillon, 2012.). Uzorci za određivanje BSS prikupljaju se iz čistih sisa. California mastitis test (CMT) je neizravna, jednostavna, orijentacijska metoda dijagnostike subkliničkog mastitisa čija je glavna namjena orijentacijski izmjeriti BSS procjenom količine DNK u mlijeku. Reagens Nalauril sulfat otapa stanične membrane, 
oslobađa se DNA i stvara se gel $u$ kontaktu s površinski aktivnom tvari. Viskoznost gela je proporcionalna broju leukocita u mlijeku (Viguier i sur., 2009., Dillon, 2012.). Za provedbu Zagrebačkog mastitis testa koristi se Zagrebački mastitis reagens. To je vodena otopina površinske aktivne tvari (alkilarilsulfonata) i indikatora $\mathrm{pH}$ kojeg proizvodi Hrvatski veterinarski institute, Zagreb, Hrvatska (Bačić, 2009.). Zagrebački mastitis test se izvodi u staji pomoću testatora i reagensa te nije potrebna dezinfekcija sisa. Testator ima četiri plitice obilježene rimskim brojevima I, II, III i IV koje označavaju svaku četvrt. Mlijeko se iz četvrti izmuze $\mathrm{u}$ pojedinu pliticu, izlije se suvišno mlijeko te se umiješa jednaka količina reagensa. Reakcija se izaziva laganim kružnim pokretima (Slika 2.).

Ukoliko nakon 2 minute mješavina ostane jednolična ili $\mathrm{s}$ tankim jasno

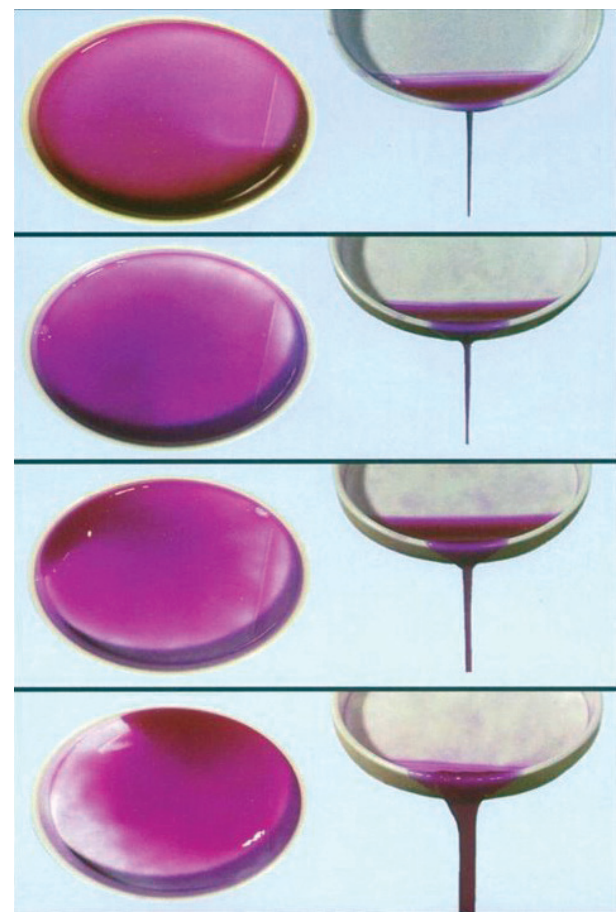

Slika 2. Slikovni prikaz rezultata ZMT (Bačić, 2009.) vidljivim nitima smatra se da je broj leukocita u $1 \mathrm{~mL}$ mlijeka do 300 000, reakcija je negativna i vime zdravo. Vidljivi se mastitis ocjenjuje ukoliko nastaje naglo grušanje želatinoznog karaktera koje se daljnjim pokretanjem ne razbija, a broj leukocita je 2000 00015000000 u 1 mL mlijeka. Ako nastaju krpičaste tvorbe ili zgrušavanje poput bjelanjka koje se kida na rubovima ocjena zdravstvenog stanja vimena je latentni ili skriveni mastitis. Normalna $\mathrm{pH}$ reakcija je sivkasto- crvena s tragovima plavog; izrazito modra mješavina označava $\mathrm{pH}$ od 7 ili više i znak je poodmakle laktacijske dobi životinja; prljavo žućkasta do žuta mješavina označava pristunost bakterija mliječnokiselog vrenja $u$ četvrti vimena i pH od 6,2 ili niže (Maćešić i sur., 2016.).

Mastitis testom se ne otkriva uzrok upale, nego se na osnovi povećanog BSS ukazuje na prisutnost nepoželjnih čimbenika.

Metoda izravnog mikroskopskog broja somatskih stanica (DMSCC) je jednostavna i jeftina metoda brojanja različitih vrsta stanica poput limfocita, neutrofila i makrofaga $u$ uzorcima mlijeka. Na odmašćeno mikroskopsko stakalce razmaže se uzorak od 5-10 $\mu \mathrm{L}$ svježeg mlijeka na površinu od $1 \mathrm{~cm}^{2}(1$ $\mathrm{cm} \times 1 \mathrm{~cm}$ ) i suši u vodoravnom položaju s $96 \%$ etilnim alkoholom 3 minute; zatim se suši na zraku, odmašćuje se ksilenom 10 minuta $i$ ispire sa $60 \%$ etilnim alkoholom 3 minute. Nakon toga se na zraku opet suši i boji se 15 in metilenskim modrilom, ispire vodom i suši na zraku. Za gledanje i razlikovanje stanica makrovijak mikroskopa je fiksiran i s obzirom na potrebe izvedbe metode mikrovijak se podešava (Dang i sur., 2008., Alhussien i Dang, 2018.).

BSS određuje se $u$ jednom mL mlijeka. Mlijeko iz neinficirane četvrti obično ima vrijednost BSS ispod 100 000/mL mlijeka. U Europi i Sjevernoj Americi granična vrijednost BSS iznosi 200 000/mL mlijeka, iako je u SAD-u zakonski postavljena 
granica na 400 000/mL. U Australiji i Novom Zelandu zakonski je određena granica vrijednosti BSS od 250 000/mL, zbog većinski pašnog načina držanja krava tijekom cijele godine. Za prikazivanje BSS koriste se mjesečna izvješća i linearna ocjena. Mjesečna izvješća omogućuju kontinuirano praćenje zdravlja vimena pojedine krave i praćenje subkliničkih mastitisa. Linearna ocjena (Linear score, SC) koristi se u SAD-u. Vrijednost LS-a od 4,0 odgovara vrijednosti BSS od 200 000/mL i koristi se za praktičnu primjenu razlikovanja zdravih i inficiranih krava. Za svaki porast LS-a za 1 udvostručuje se vrijednost BSS (Bačić, 2009.).

\section{Čimbenici koji utječu na BSS}

Mnogo čimbenika utječe na BSS na razini pojedine krave $\mathrm{i}$ na razini stada. Sposobnost ispravnog tumačenja BSS ovisi o razumijevanju čimbenika koji mogu utjecati na njihov broj. Laktacija se muznih krava može podijeliti na: ranu, srednju i kasnu laktaciju. Mliječnost je najveća tijekom rane laktacije,a pomakom se smanjuje. BSS je najviši nakon teljenja, smanjuje se između 25 . i 45. dana, a zatim se polako tijekom ostatka laktacijskog ciklusa diže (Kennedy i sur., 1982., Alhussien i Dang, 2018.). Srednja vrijednost BSS u mlijeku prve laktacije je veća tijekom rane laktacije $\left(1,10-1,27 \times 10^{5}\right.$ stanica/mL), smanjuje se tijekom srednje laktacije $\left(0,90-0,99 \times 10^{5}\right.$ stanica/mL), a zatim se neznatno povećava tijekom kasne laktacije $\left(0,99-1,07 \times 10^{5}\right.$ stanica/ mL) (Singh i Ludri, 2000., Alhussien i Dang, 2018.). U odnosu na ranu i kasnu laktaciju visokomliječne krave imaju bolji urođeni imunsni odgovor tijekom srednje faze laktacije (Mukherjee i sur., 2013., Alhussien i Dang, 2018.). U starijih krava povećan je BSS, kao i tijekom estrusa te naglih promjena obroka i načina držanja. Visokomliječne pasmine krava zbog velike fiziološke opterećenosti i smanjene otpornosti organizma pokazuju veću sklonost pojavi mastitisa. U holštajnskih krava BSS je najviši na početku laktacije. Geografsko područje i godišnje doba su usko povezani s hranidbom. U ljetnom razdoblju hrana je kvalitetnija, a krave su u boljoj tjelesnoj kondiciji te je BSS je u mlijeku najmanji (Havranek i Rupić, 2003., Čačić i sur., 2003.). Pasmina također utječe i na oblik vimena. Viseći oblik vimena ima veću učestalost mastitisa $\mathrm{u}$ odnosu na vime $\mathrm{s}$ dobro povezanim sisama (Dang i sur., 2007., Ahlawat i sur., 2008., Alhussien i Dang, 2018.) BSS je uvijek veći kod kraćih sisa koje imaju veći promjer sisnog kanala (Sharma i sur., 2016., Alhussien i Dang, 2018). Mlade prvotelkinje proizvode manje mlijeka i imaju niži BSS u mlijeku $\mathrm{u}$ usporedbi s kravama koje su se telile više puta (Saravanan i sur., 2015., Alhussien i Dang, 2018., Gonçalves i sur., 2018.). S povećanjem dobi prvotelkinja raste i broj BSS u mlijeku (Schultz i sur., 1990., Čačić i sur., 2003.). Gubitak tjelesne težine tijekom rane faze laktacije utječe na smanjenje BSS, a povećanje tjelesne težine utječe na povećanje BSS. Veća varijabilnost tjelesne težine utječe i na veću vjerojatnost razvoja kliničkog oblika mastitisa. U usporedbi sa strojnom mužnjom BSS je u mlijeku ručno pomuženih krava veći. Umakanje sise $\mathrm{u}$ antimikrobno sredstvo $\mathrm{u}$ mlijeku tijekom sljedećih mužnji smanjuje BSS. Moderni strojevi imaju ugrađene brojače somatskih stanica. BSS 48 mjeseci nakon instalacije je uspoređen s BSS 24 mjeseca prije instalacije (Alhussien i Dang, 2018.). BSS je rastao do 12 mjeseci nakon instalacije modernih strojeva, no vremenom se smanjivao te je 36 mjeseci nakon instalacije bio manji nego prije. Automatska mužnja ima negativan utjecaj na kakvoću mlijeka tijekom rane faze, no nakon faze prilagodbe, koja u prosjeku traje 188,5 dana (Castro i sur., 2017., Alhussien i Dang, 2018.) kakvoća mlijeka se znatno poboljšava (Tabela 2). 


\section{Mlijeko}

Mlijeko je biološka tekućina vrlo složena sastava žućkastobijele boje, karakterističnog okusa i mirisa. Glavni sastojci mlijeka su voda i suha tvar u koju ubrajamo mliječne masti, mliječne bjelančevine i mliječni šećer (Bačić, 2009). Voda se u mlijeku nalazi u slobodnom obliku i kao vezana za bjelančevine, masti i laktozu. Slobodna voda pri 100 ${ }^{\circ} \mathrm{C}$ prelazi u paru. Osim nabrojanog, mlijeko sadrži velik broj antimikrobnih tvari koje sprječavaju nastanak infekcije. Antimikrobne tvari su prisutne $\mathrm{u}$ vrlo malim koncentracijama, ali iznimno važno djeluju na održavanje kakvoće i sigurnosti mlijeka. Mast se u mlijeku nalazi u vidu kuglica koje se naziavaju masnim kapljicama i promjera su od 0,1 $\mu \mathrm{m}$ do $22 \mu \mathrm{m}$ s prosječnom vrijednošću od 1-6 $\mu \mathrm{m}$. Mliječna mast utječe na aromu, konzistenciju i teksturu mliječnog proizvoda, predstavlja najvarijabilniji sastojak mlijeka, a prema Pravilniku o utvrđivanju sastava sirovog mlijeka (NN 27/2017) mora biti najmanje $3 \%$, a najviše 5,5 \% mliječne masti. Masne kiseline kratkih i srednjedugih lanaca nastaju u mliječnoj žlijezdi iz octene i $\beta$-hidroksimaslačne kiseline. Masne kiseline dužih lanaca su podrijetlom iz masnog tkiva ili su krvlju iz jetre prenesene $u$ vime. Od zasićenih masnih kiselina najzastupljenije su: miristinska, palmitinska i stearisnka, a od nezasićenih oleinska masna kiselina. Neposredno nakon mužnje mast se $u$ mlijeku nalazi u vidu emulzije, a stajanjem i hlađenjem mlijeka zbog kristalizacije masnih kiselina prelazi u suspenziju. Mliječne bjelančevine se $\mathrm{u}$ mlijeku nalaze $\mathrm{u}$ dva oblika različitog kemijskog sastava: 80 \% kazein i $20 \%$ proteini sirutke. Kazein je najvažnija složena bjelančevina mlijeka, a sintetizira se u stanicama žljezdanog epitela vimena i sastoji se od frakcija $\alpha, \beta, \gamma$ i $\kappa$. U mlijeku se nalazi u obliku koloidnih čestica, micela. Proteini sirutke su bjelančevine koje nakon izdvajanja kazeina ostaju u mliječnom serumu. U proteine sirutke se ubrajaju $\alpha$-laktoglobulin, $\quad \beta$-laktoglobulin i albumini krvnog seruma. Prema Pravilniku o utvrđivanju sastava sirovog mlijeka (NN 27/2017.) mora biti najmanje $2,5 \%$, a najviše $4 \%$ bjelančevina (Tabela 1). Laktoza je specifičan proizvod mliječne žlijezde i nalazi se samo $u$ mlijeku. To je disaharid sastavljen od glukoze i galaktoze. Glukoza prelazi direktno iz krvi u stanice mliječne žlijezde, a galaktoza nastaje iz glukoze preko galakto-6-fosfata. Sadržaj laktoze u mlijeku ovisi o zdravstvenom stanju mliječne žlijezde i u krava iznosi 4,7 $\%-4,9 \%$. Oblici laktoze su $\alpha$ i $\beta$ koji imaju ista kemijska svojstva, a razlikuju se po konfiguraciji $\mathrm{H}$ i $\mathrm{OH}$ grupe na prvom ugljikovom atomu (Tratnik, 1998.).

Za ocjenu kakvoće mlijeka koristi se prirodni sastav mlijeka te organoleptički nalaz, kvalitativno-kvantitativni sastav bakterijske flore i još čitav niz drugih pokazatelja. Smatra se da na kakvoću mlijeka neposredno utječu zdravlje i način držanja muzara, održavanje načela higijene pri sabiranju u postupku s mlijekom do potrošača, tehničke mogućnosti za čuvanje prirodnog sastava mlijeka i zdravlje osoba koje rukuju s mlijekom (Dobranić, 2006.). Svježe pomuženo mlijeko pogoduje rastu i razvoju mikroorganizama zbog čega se u proizvodnji i preradi koriste visoki higijenski standardi. Unutrašnjost vimena, vanjska površina bradavica na vimenu i njihova neposredna okolina te mužnja i pribor za mužnju su glavni izvori mikroorganizama u mlijeku. Smatra se da mikroorganizmi iz okoline u mlijeko mogu dospjeti, iz zraka i vode, s površine sisa i vimena, s ruku muzača i njegove odjeće, iz stroja za mužnju i mljekarske opreme, ako nisu redovito čišćeni i dezinficirani. Uz sve navedeno, važan parametar zdravstvenog stanja vimena i kakvoće mlijeka je BSS u $1 \mathrm{~mL}$ mlijeka. 
Tabela 1. Razvrstavanje mlijeka u razrede sukladno članku 17. Pravilnika o utvrđivanju sastava sirovog mlijeka (NN 27/2017.)

\begin{tabular}{c|c|c|c|}
\multirow{2}{*}{ Vrsta mlijeka } & \multirow{2}{*}{ Razred } & \multicolumn{2}{|c|}{ Geometrijski prosjek } \\
\cline { 3 - 4 } & & Mikroorganizmi (u 1 mL) & Somatske stanice (u 1 mL) \\
\hline \multirow{2}{*}{ Mlijeko } & I & $\leq 100.000$ & $\leq 400.000$ \\
\hline & II & $>100.000$ & $>400.000$
\end{tabular}

U Hrvatskoj je Pravilnikom o utvrđivanju sastava sirovog mlijeka (NN 27/2017.) uređeno razvrstavanje mlijeka u razrede prema broju mikroorganizama i BSS (Anonymous, 2017.). Navedena vrijednost nije gornja fiziološka vrijednost somatskih stanica u zdravoj mliječnoj žlijezdi već ju uvjetuju mljekarskotehnički i ekonomski razlozi (Havranek i Rupić, 2003.).

\section{Rasprava}

Laktoza se sintetizira u Golgijevom aparatu sekretornih stanica mliječne žlijezde pomoću enzima galaktozil transferaze i alfa laktalbumina, a supstrat za sintezu laktoze je glukoza iz krvi. Pri upalnom procesu kroz mliječnu žlijezdu protiče manja količina krvi pa na taj način dolazi i manja količina glukoze što za posljedicu ima smanjenje laktoze. Kod mastitisa je oštećeno i tkivo pri čemu dolazi do smanjenja sintetske sposobnosti enzimatskih stanica $u$ sekretornim stanicama. Smanjenje količine laktoze u citosolu dovodi do promjene osmotskog tlaka na staničnoj membrani što ima za posljedicu prelazak iona iz krvi u mlijeko. Kao rezultat infekcije mliječne žlijezde nastaje smanjenje postotka masti. Naročito značenje se daje povećanju sadržaja slobodnih masnih kiselina. Mlijeko krava s mastitisom sadrži veći posototak esterificiranih masnih kiselina (C4-C12), a manji postotak zasićenih masnih kiselina (C16:0-C18:0). Pored promjena na membrani, masne kapljice mlijeka krava s mastitisima osjetljivije su na spontanu i induciranu lipolizu pa je u takvom mlijeku velika koncentracija slobodnih masnih kiselina. Ukupna se količina proteina $\mathrm{u}$ mlijeku pri mastitisima ne mijenja. Međutim, ustvrđeno je smanjenje proteina koji se sintetiziraju u sekretornim stanicama ( $\alpha$-kazein, $\beta$-kazein, $\alpha$-laktoglobulin, $\beta$-laktalbumin), a povećavanje proteina podrijetom iz krvi (serum albumini i imunoglobulini). U mlijeku krava s mastitisima ustvrđenoje znatno povećanje parakapa kazeina, niohovo povećanje nastaje kao posljedica povećanja aktivnosti proteaza iz leukocita. Mastitisi dovode do promjene odnosa topivog i micelarnog kazeina. Mlijeko zdravih krava ima $95 \%$ micelarnog kazeina, a mlijeko bolesnih $46 \%$. Porast topivog kazeina direktno utječe na sposobnost mlijeka za proizvodnju fermentiranih proizvoda. Bakterijska infekcija mliječne žlijezde izaziva oštećenje žlijezdanog epitela što se vidi stvaranjem malih prolaza između sekretornih stanica i povećanja permeabiliteta krvnih kapilara. Stoga, $\mathrm{Na}^{+}$i $\mathrm{Cl}^{-}$u cilju održavanja somatskog tlaka prelaze u lumen alveola, a $\mathrm{K}^{+}$se proporcionalno smanjuje. Zbog povećane propustljivosti krvnih kapilara dolazi do prolaska iona bikarbonata iz krvi u mlijeko, pa se zapaža i promjena $\mathrm{pH}$.

Promjene u sastavu mlijeka izazvane mastitisima utječu na podobnost mlijeka za tehnološku obradu. Porast proteina sirutke smanjuje termostabilnost mlijeka. Proteini sirutke adsorbirani na micele kazeina termički obrađenog mlijeka smanjuju njegovu sposobnost podsiravanja i formiranje gruša. 
Promjene odnosa kazeinskih frakcija kao i pojava parakapa kazeina utječu na formiranje micela kazeina, što za posljedicu ima slab randman i lošu kakvoću gruša, koja se očituje u niskoj rentabilnosti pri preradi mlijeka u sir. Zbog zadržavanja veće količine vode produženo je vrijeme podsiravanja mlijeka krava oboljelih od mastitisa, a rok trajanja sireva proizvedenog od takvog mlijeka je smanjen. Povećanje imunoglobulina u mlijeku kao posljedica odgovara na infekciju mliječne žlijezde utječe na fermentativnu sposobnost mlijeka. Pojedini uzročnici mastitisa mogu izazvati stvaranje antitijela koji regiraju $\mathrm{s}$ mliječnokiselinskim bakterijama i inhibiraju njihovo razmnožavanje u mlijeku. Termičkom obradom se smanjuje negativno djelovanje veće količine imunoglobulina na fermentativnu sposobnost mlijeka. Zbog smanjene termostabilnosti, mlijeko krava s mastitisima nije pogodna sirovina za proizvodnju kondenziranog mlijeka, mlijeka u prahu i steriliziranog mlijeka. Pored direktnog utjecaja mastitisa na podobnost mlijeka za preradu, mastitis i indirektno djeluje na kakvoću mlijeka. Pri tome značajno mjesto imaju antibiotici koji se kao rezidue javljaju u mlijeku poslije liječenja bolesnih krava. Nepravilan postupak s mlijekom krava nakon liječenja može znatno pridonijeti inhibiciji razmnožavanja mliječnokiselih bakterija pri proizvodnji fermentiranih proizvoda (Stojanović i Katić, 1997.).

Najveći rizik za ljudsko zdravlje je konzumacija nepasteriziranog ili nepropisno pasteriziranog mlijeka (Oliver i sur., 2005., Sharma i sur., 2011.). Održivi patogeni i njihovi toksini mogu se prenijeti izravno na ljude. Mycobacterium avium subsp. paratuberculosis, povezana s Johnovom bolesti goveda (paratuberkuloza) i izolirana iz bolesnika s Crohnovom bolešću, može preživjeti neke prihvaćene postupke pasterizacije.

Tabela 2. Varijacije u kakvoći kravljeg mlijeka u odnosu na BSS (Alhussien i sur., 2016.a,b, Alhussien i Dang, 2018.J

\begin{tabular}{|l|c|c|c|}
\hline SASTAV MLIJEKA & $\begin{array}{c}\text { MLIJEKO ZDRAVE } \\
\text { KRAVE }\end{array}$ & $\begin{array}{c}\text { MLIJEKO KRAVE } \\
\text { SA SUBKLINIČKIM } \\
\text { MASTITISOM }\end{array}$ & $\begin{array}{c}\text { MLIJEKO KRAVE S } \\
\text { MASTITISOM }\end{array}$ \\
\hline BSS $\left(10^{5} \mathrm{st} / \mathrm{mL}\right)$ & $<2$ & $3-5$ & $>5$ \\
\hline Masti $(\%)$ & 4,32 & 4,31 & 4,08 \\
\hline Proteini (\%) & 3,30 & 3,34 & 3,70 \\
\hline Kazein & 2,70 & 2,55 & 2,25 \\
\hline Proteini sirutke & 0,84 & 1,13 & 1,35 \\
\hline Albumini seruma & 0,17 & 0,24 & 0,37 \\
\hline Laktoza (\%) & 4,84 & 4,71 & 4,41 \\
\hline SNF (\%) & 9,73 & 9,61 & 9,35 \\
\hline pH & 6,61 & 6,63 & 6,80 \\
\hline EC (mS/cm) & 5,90 & 6,01 & 7,21 \\
\hline Klorid & 0,09 & 0,13 & 0,16 \\
\hline Natrij & 0,05 & 0,09 & 0,11 \\
\hline Kalij & 0,18 & 0,16 & 0,13 \\
\hline
\end{tabular}


Pravilna pasterizacija je vrlo učinkovita u sprečavanju prijenosa održivih patogena iz mlijeka na ljude.

Mnogi čimbenici i načini upravljanja farmom utječu na povećanje ili smanjenje BSS stanica u mlijeku (Syridion i sur., 2012., Vissio i sur., 2018., Alhussien i Dang, 2018). Mjere opreza tijekom muznih postupaka povezane sa smanjenjem BSS u stadu su: nošenje rukavica tijekom mužnje, automatske muzilice, dezinfekcija sisa nakon mužnje, redoviti godišnji pregled muznog uređaja i držanje krava da stoje nakon mužnje, slobodan način držanja, uporaba pijeska za stelju, održavanje higijene ležišta nakon porođaja, monitoring krava $\mathrm{u}$ suhostaju, primjena terapije $\mathrm{u}$ suhostaju, redovita primjena mastitis testa doprinose snižavanju BSS.

Prehrambeni dodatci s vitaminima i mineralima poboljšavaju imunost životinje i stoga smanjuju BSS. Uporaba vitamina E (500 IU/životinja/dan) i selena (6 mg/životinji/dan) korišteni zasebno ili u kombinaciji tijekom rane laktacije kroz dva mjeseca smanjuje BSS s 29,39 x $10^{5}$ na $8,28 \times 10^{5}$ stanica/mL mlijeka (Sharma i Maiti, 2005., Sharma i sur., 2011.). (Slika 3.) Također, korištenje antibiotika prije teljenja učinkovito smanjuje BSS iz pojedinih četvrti.

Genetsko poboljšanje mliječnosti popraćeno je povećanom genetskom osjetljivošću na mastitis stoga je važno odabirom zdravstvenih svojstava vimena neutralizirati neželjeni genetski efekt osjetljivosti na mastitis (Shook, 1993., Rogers i sur., 1998., Sharma i sur., 2011.). Korištenjem cjepiva MASTIVAC I smanjuje se broj životinja zaraženih bakterijom $S$. aureus, poboljšava se cjelokupno zdravlje mliječne žlijezde, raste kakvoća i količina proizvodnje mlijeka te se smanjuje BSS (Leitner i sur., 2004., Alhussien i Dang, 2018.). Biološkim istraživanjima pod nazivom Omics otkriveno je da su metaboliti poput hipurata i fumarata povezani s nižim BSS mlijeka, dok su laktat, butirat, izoleucin, acetat i $\beta$-hidroksibutirat povezani s visokim vrijednostima BSS (Sundekilde i sur., 2013., Alhussien i Dang, 2018.).

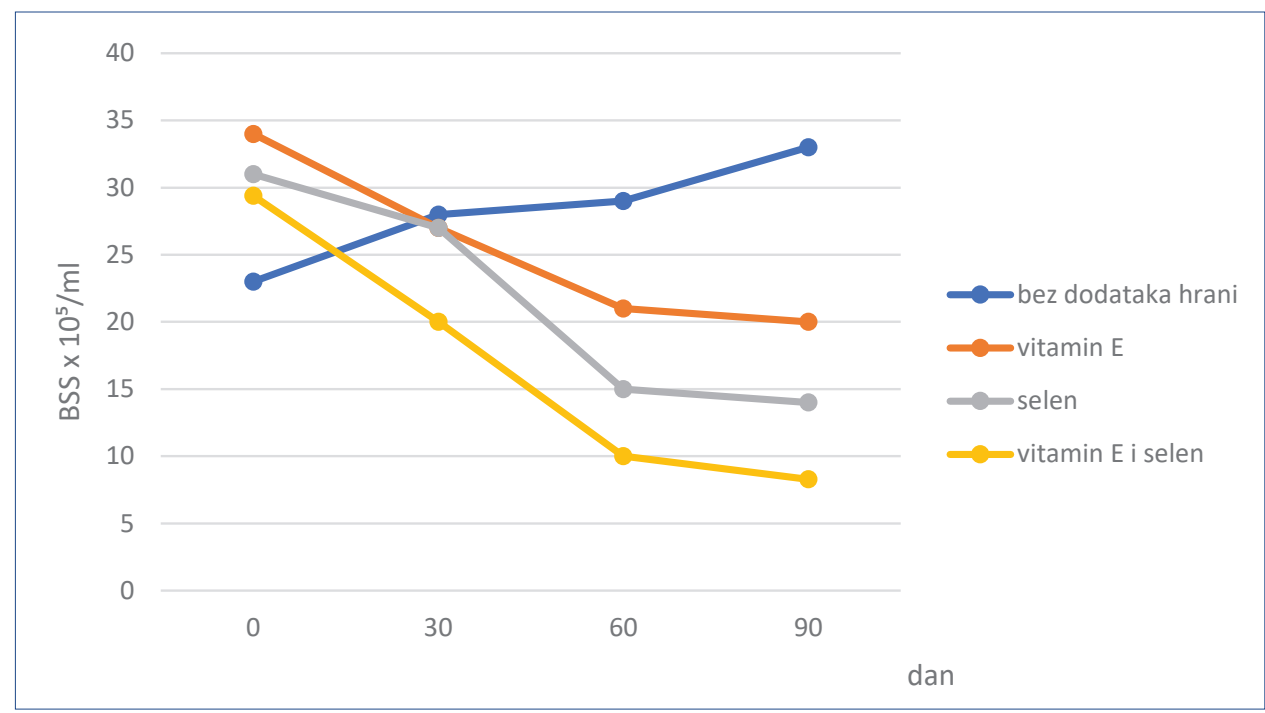

Slika 3. Utjecaj vitamina E i selena na BSS u različitim vremenskim intervalima tijekom rane laktacije (Sharma i Maiti, 2005., Sharma i sur., 2011.) 


\section{Zaključci}

Mastitis je jedan od najpristnijih problema na farmama mliječnih krava koji prouzroči najveće ekonomske posljedice. Mastitis prouzroči povećanje BSS zbog povećane propusnosti krvnih žila i povećanog ljuštenja epitelnih stanica u mlijeko. Povećani BSS dovodi do smanjenja postotka mliječne masti i laktoze, povećanja ukupnog broja proteina, izvanstaničnih iona i povećanja električne provodljivosti. Mlijeko krava s mastitisom ima smanjenu termostabilnost te mu je smanjena sposobnost podsiravanja i formiranja gruša. Takvo mlijeko ima užegli okus i nije pogodno za proizvodnju kondenziranog mlijeka, mlijeka u prahu i steriliziranog mlijeka. Redovita dezinfekcija sisa vimena prije i poslije mužnje, klinički pregled vimena te povoljni zoohigijenski uvjeti držanja imaju pozitivan učinak na ukupan BSS u mlijeku krava.

\section{Literatura}

1. AHLAWAT, K., A. K. DANG and C. SINGH (2008): Relationships of teat and udder shape with milk SCC in primiparous and multiparous Sahiwal cows. Indian J. Dairy Sci. 61, 152-156.

2. ALHUSSIEN, M. and A. K. DANG (2018): Milk somatic cells, factors influencing their release, future prospects and practical utility in dairy animals. Vet. World 11, 562-557.

3. ALHUSSIEN, M., M. KAUR, P. MANJARI, S. P. KIMOTHI, A. K. MOHANTY and A. K. DANG (2015): A comparative study on the blood and milk cell counts of healthy, subclinical, and clinical mastitis Karan fries' cows. Vet. World 8, 685-689.

4. ALHUSSIEN, M., P. MANJARI, A. A. SHEIKH, S. M. SEMAN, S. REDDI, A. K. MOHANTY and A. K. DANG (2016a): Immunological attributes of blood and milk neutrophils isolated from crossbred cows during different physiological conditions. Czech J. Anim. Sci. 61, 223-231.

5. ALHUSSIEN, M., P. MANJARI, S. MOHAMMED, A. A. SHEIKH, S. REDDI, S. DIXIT and A. K. DANG (2016b): Incidence of mastitis and activity of milk neutrophils in Tharparkar cows reared under semiarid conditions. Trop. Anim. Health Prod. 48, 12911295

6. Anon. (2017): Pravilnik o utvrđivanju sastava sirovog mlijeka. Ministarstvo poljoprivrede Republike Hrvatske. NN 27/2017.
7. ARGAW, A. (2016): Review on epidemiology of clinical and subclinical mastitis on dairy cows. Food Sci. Qual. Manag. 52, 56-65.

8. BAČIĆ, G. (2009): Dijagnostika i liječenje mastitisa u goveda. Veterinarski fakultet Sveučilišta u Zagrebu, Zagreb. str. 17-43.

9. BENIĆ, M., B. HABRUN and G. KOMPES (2012): Clinical and epidemiological aspects of cow mastitis caused by S. aureus and its methicilinresistent strains. Rad Hrvatske akademije znanosti i umjetnosti 511, 113-122.

10. BENIĆ, M., N. MAĆEŠIĆ, L. CVETNIĆ, B. HABRUN, Ž. CVETNIĆ, R. TURK, D. ĐURIČIĆ, M. LOJKIĆ, V. DOBRANIĆ, H. VALPOTIĆ, J. GRIZELJ, D. GRAČNER, J. GRBAVAC and M. SAMARDŽIJA (2018): Bovine mastitis: a persistent and evolving problem requiring novel approaches for its control - a review. Vet. arhiv 88, 535-557.

11. BUROVIĆ, J. (2020): Isolation of bovine clinical mastitis bacterial pathogens and their antimicrobial susceptibility in the Zenica region in 2017. Vet stn. 51, 47-52. (In Croatian).

12. ČAČIĆ, Z., S. KALIT, N. ANTUNAC i M. ČAČIĆ (2003): Somatske stanice i čimbenici koji utječu na njihov broj u mlijeku. Mljekarstvo 53, 23-36.

13. CALVINHO, L. F. and L. TIRANTE (2005): Prevalencia de microorganismos patógenos de mastitis bovina y evolución del estado de salud de la glándula mamaria en Argentina en los últimos 25 años. Revista FAVE. 4, 29-40.

14. CARRILLO-CASAS, E. M. and R. E. MIRANDAMORALES (2012): Bovine Mastitis Pathogens: Prevalence and Effects on Somatic Cell Count. Milk Production - An Up-to-Date Overview of Animal Nutrition, Management and Health. 359-364.

15. CASTRO, A., J. M. PEREIRA, C. AMIAMA and M. BARRASA (2017): Long-term variability of bulk milk somatic cell and bacterial counts associated with dairy farms moving from conventional to automatic milking systems. Ital. J. Anim. Sci. 17, 218-225.

16. CVETNIĆ, L., M. SAMARDŽIJA, B. HABRUN, G. KOMPES and M. BENIĆ (2016): Microbiological monitoring of mastitis pathogens in the control of udder health in dairy cows. Slov. Vet. Res. 53, 131-140.

17. CVETNIĆ, L., M. SAMARDŽIJA, S. DUVNJAK, B. HABRUN, M. CVETNIĆ, V. JAKI TKALEC, D. ĐURIČIĆ and M. BENIĆ (2021): Multi Locus Sequence Typing and spa Typing of Staphylococcus aureus Isolated from the Milk of Cows with Subclinical Mastitis in Croatia. Microorganisms 9, 725, doi.org/10.3390/microorganisms 9040725

18. DANG, A. K, S. KAPILA, P. TOMAR and S. SINGH (2007): Immunity of the buffalo mammary gland during different physiological stages. Asian Aust. J. Anim. Sci. 20, 1174-1181.

19. DANG, A. K., S. KAPILA, C. SINGH and J. P. SEHGAL (2008): Milk differential cell counts and compositional changes in cows during different physiological stages. Milchwissenschaft. 63, 239-242.

20. DILLON, D. (2012): An Evaluation of traditional, novel and prospective cow-side tests in approach to mastitis 
diagnosis. Faculty of Veterinary Medicine, Szent Istvan University, Department of Animal Hygiene.

21. DOBRANIĆ, V. (2006): Nalaz i utjecaj gljivica na higijensku kakvoću kravljeg mlijeka. Doktorska disertacija, Veterinarski faklultet, Zagreb.

22. GONÇALVES, J. L., R. I. CUE, B. G. BOTARO, J. A. HORST, A. A. VALLOTO and M. V. SANTOS (2018): Milk losses associated with somatic cell counts by parity and stage of lactation. J. Dairy Sci. 80, 3219.

23. GRAČNER, D., LJ. BEDRICA, M. CERGOLJ, I HARAPIN, M.SAMARDŽIJA, G. GREGURIĆ GRAČNER, D. ŽUBČIĆ, J. REŠETIĆ and M. FURY (2006): Haptoglobinspielel in Blut und Milch von Kuhen mit einer Staphylokokkenmastitis. Tierärtzl. Umschau 61, 636-641.

24. GUARÍN, J. F., M. G. PAIXÃO and P. L. RUEGG (2017): Association of anatomical characteristics of teats with quarter-level somatic cell count. J. Dairy Sci. 100, 1-10.

25. HARMON, R. J. (1994): Physiology of mastitis and factors affecting somatic cell count. J. Dairy Sci. 77, 2103-2112.

26. HAVRANEK, J. i V. RUPIĆ (2003): Mlijeko od farme do mljekare. Hrvatska mljekarska udruga, Zagreb. str. 29-44.

27. HIITIÖ, H., J. VAKKAMÄKI, H. SIMOJOKI, T. AUTIO, J. JUNNILA, S. PELKONEN and S. PYÖRÄLÄ (2017): Prevalence of subclinical mastitis in Finnish dairy cows: changes during recent decades and impact of cow and herd factors. Acta Vet. Scand. 59, 22.

28. KENNEDY, B. W., M. S. SETHAR, A. K. W. TONG, J. E. MOXLEY and B. R. DOWNEY (1982): Environmental factors influencing test-day somatic cell counts in Holsteins. J. Dairy Sci. 65, 275-280.

29. KOVAČIĆ, M., M. SAMARDŽIJA, D. ĐURIČIĆ, S. VINCE, Z. FLEGAR-MEŠTRIĆ, S. PERKOV, D. GRAČNER and R. TURK (2019): Paraoxonase-1 activity and lipid profile in dairy cows with subclinical and clinical mastitis. J. Appl. Anim. Res. 47, 1-4.

30. LAM, T. J. G. M., R. G. OLDE RIEKERINK, O. C. SAMPIMON and H. SMITH (2009): Mastitis diagnostics and performance monitoring. Ir. Vet J. 62, 34-39.

31. LEE, D. H. and V. CHOUDHARY (2006): Study on Milkability Traits in Holstein Cows. AsianAustralas J. Anim. Sci. 19, 309-314.

32. LEITNER, G., O. KRIFUCKS, A. GLICKMAN, Y. VAADIA, S. FRIEDMAN, E. EZRA and Z. TRAININ (2004): MASTIVAC I: Staphylococcus aureus vaccineprevention of new udder infection and therapeutic effect on cows chronically infected with $S$. aureus under field conditions. Isr. J. Vet. Med. 59, 15-23.

33. MAĆEŠIĆ, N., T. KARADJOLE, G. BAČIĆ, M. BENIĆ, M. KARADJOLE, S. VINCE, M. LIPAR and M. CERGOLJ (2012): Aetiology and prevalence of bovine intramammary infection at drying off. Vet. arhiv 82, 125-131.

34. MAĆEŠIĆ, N., G. BAČIĆ, K. BOŽIĆEVIĆ, M. BENIĆ, T. KARADJOLE, N. PRVANOVIĆ BABIĆ, M. LOJKIĆ, M. EFENDIĆ, I. BAČIĆ, and M. PAVLAK (2016): Assessment of the Zagreb mastitis test in diagnosis of subclinical mastitis in dairy cattle. Vet. arhiv 86, 475-485.

35. MILLER, R. H. and M. J. PAAPE (1985): Relationship between milk somatic cell count and milk yield. Proc. Ann. Mtg. Natl. Mastitis Counc. P. 60.

36. MUKHERJEE, J., N. VARSHNEY, M. CHAUDHURY, A. K. MOHANTY and A. K. DANG (2013): Immune response of the mammary gland during different stages of lactation cycle in high versus low yielding Karan Fries crossbred cows. Livestock Sci. 154, 215-223.

37. NATIONAL MASTITIS COUNCIL (1999): Microbiological Procedures for the Diagnosis of Bovine Udder Infection. National Mastitis Council. $3^{\text {rd }}$ ed. Arlington, Virginia, USA.

38. NEDIĆ, S., S. VAKANJAC, M. SAMARDŽIJA and S. BOROZAN (2019): Paraoxonase 1 in bovine milk and blood as marker of subclinical mastitis caused by Staphylococcus aureus. Res. Vet. Sci. 125, 323-332.

39. OLIVER, S. P., B. M. JAVARAO and R. A. ALMEIDA (2005): Foodborne pathogens, mastitis, milk quality, and dairy food safety. Proc. $44^{\text {th }}$ NMC Annual Meeting. Orlando, FL. 3-27.

40. ROGERS, G. W., G. BANOS, U. SANDER NIELSEN and J. PHILIPSSON (1998): Genetic correlations among somatic cell scores, productive life, and type traits from the United States and udder health measures from Denmark and Sweden. J. Dairy Sci. 81, 1445-1453.

41. SAIDI, R., Z. CANTEKIN, N. MIMOUNE, Y. ERGUN, H. SOLMAZ, D. KHELEF and R. KAIDI (2021): Investigation of the presence of slime production, VanA gene and antiseptic resistance genes in Staphylococci isolated from bovine mastitis in Algeria. Vet. stn. 52, 57-63.

42. SANDHOLM, M., T. HONKANEN-BUZALSKI, L. KAARTINEN and S. PYÖR̈̈LÄ (1995): The bovine udder and mastitis. Gummerus, Jyväskylä, Finland. 121-141.

43. SARAVANAN, R., D. N. DAS, S. DE and S. PANNEERSELVAM (2015): Effect of season and parity on somatic cell count across zebu and crossbred cattle population. Indian J. Anim. Res. 49, 383-387.

44. SHARMA, N. and S. K. MAITI (2005): Effect of dietary supplementation of vitamin $\mathrm{E}$ and selenium in sub clinical mastitis in dairy cows. Indian J. Vet. Med. 25, 76-79.

45. SHARMA, N., N. K. SINGH and M. S. BHADWAL (2011): Relationship of Somatic Cell Count and Mastitis: An Overview. Asian-Aust. J. Anim. Sci. 3, 429-438.

46. SHARMA, T., D. P. KUMAR, P. R. GHOSH, D. BANERJEE, D. B. CHANDRA and J. MUKHERJEE (2016): Alteration in the in vitro activity of milk leukocytes during different parity in high yielding cross-bred cows. Biol. Rhythm. Res. 47, 519-527.

47. SHOOK, G. E. (1993): Genetic improvement of mastitis through selection on somatic cell count. Vet. Clin. North Am. Food Anim. Pract. 9, 563-581.

48. SINGH, M. and R. S. LUDRI (2000): Somatic cell counts in Murrah buffaloes (Bubalus bubalis) during different stages of lactation, parity and season. Asian Aust. J. Anim. Sci. 14, 189-192. 
49. STOJANOVIĆ, L. i V. KATIĆ (1998): Higijena Mleka. Veterinarski fakultet, Univerzitet $u$ Beogradu, Srbija.

50. SUNDEKILDE, U. K., N. A. POULSEN, L. B. LARSEN and H. C. BERTRAM (2013): Nuclear magnetic resonance metabonomics reveals strong association between milk metabolites and somatic cell count in bovine milk. J. Dairy Sci. 96, 290-299.

51. SYRIDION, D., S. S. LAYEK, K. BEHERA, T. K. MOHANTY, A. KUMARESAN, A. MANIMARAN, A. K. DANG and S. PRASAD (2012): Effects of parity, season, stage of lactation, and milk yield on milk somatic cell count, $\mathrm{pH}$ and electrical conductivity in crossbred cows reared under subtropical climatic conditions. Milchwissenschaft 67, 362-365.

52. TÄNAVOTS, A., H. KIIMAN, E. ALTOSAAR, T. KAART and H. VIINALASS (2015): Milk leakage from the udder of cows on dairy farms with automatic and conventional milking system. Vet. Med. Zoot. 69, 71-78.
53. TRATNIK, Lj. (1998): Mlijeko - tehnologija, biokemija i mikrobiologija. Zagreb. Hrvatska mljekarska udruga.

54. TURK, R., C. PIRAS, M. KOVAČIĆ, M. SAMARDZ̈IJA, H. AHMED, M. DE CANIO, A. URBANI, Z. FLEGAR MEŠTRIĆ, A. SOGGIU, L. BONIZZI and P. RONCADA (2012): Proteomics of inflammatory and oxidative stress response in cows with subclinical and clinical mastitis. J. Proteomics 75, 4412-4428.

55. TURK, R., M. KOLEDIĆ, N. MAĆEŠIĆ, M. BENIĆ, V. DOBRANIĆ, D. ĐURIČIĆ, L. CVETNIĆ and M. SAMARDŽIJA (2017): The role of oxidative stress and inflammatory response in the pathogenesis of mastitis in dairy cows. Mljekarstvo 67, 91-101.

56. VIGUIER, C., S. ARORA, N. GILMARTIN, K. WELBECK and R. O'KENNEDY (2009): Current trends and future perspectives. Cell Press 27, 486-490.

57. VISSIO, C., M. BOUMAN and A. J. LARRIESTRA (2018): Milking machine and udder health management factors associated with bulk milk somatic cell count in Uruguayan herds. Prev. Vet. Med. 150, 110-116.

\section{Use of somatic cell count in the diagnosis of mastitis and its impacts on milk quality}

Klara KNEŽEVIĆ, DVM, Biognost, Zagreb, Croatia; Vesna DOBRANIĆ, DVM, PhD, Full Professor, Marko SAMARDŽIJA, DVM, PhD, Full Professor, Iva GETZ, DVM, PhD, Associate Professor, Maša EFENDIĆ, DVM, Juraj ŠAVORIĆ, DVM, Assistant, Ivan BUTKOVIĆ, DVM, Assistant, Marija CVETNIĆ, DVM, Assistant, Nino MAĆEŚIĆ, DVM, PhD, Associate Professor, Faculty of Veterinary Medicine University of Zagreb, Croatia; Dražen ĐURIČIĆ, DVM, PhD, Assistant Professor, Mount-trade, Garešnica, Croatia; Miroslav BENIĆ, DVM, PhD, Assistant Professor, Luka CVETNIĆ, DVM, PhD, Croatian Veterinary Institute, Zagreb, Croatia; Marin MAZIĆ, Veterinary Practice Marković, Zagreb, Croatia

Mastitis is an inflammatory reaction to an infection of the secretory part of the mammary gland. The causes of mastitis are divided by Gram staining into Gram-positive and Gram-negative, and according to aetiology into contagious and environmental causes. Contagious pathogens are most transmitted during milking, and cause long-lasting, chronic mastitis with a mostly subclinical course. In contrast, environmental pathogens typically cause short-term infections, but with more frequent clinical manifestations. Infected cows are detected by the diagnosis of mastitis, which is most often reached through indirect or direct methods of determining the somatic cell count and by conducting bacteriological examination of milk. The Zagreb mastitis test is a quick and simple orientation method for estimating the number of somatic cells. Its advantage is that can be performed in field conditions. Somatic cells are made up of epithelial cells and leukocytes. They are normally found in milk, but their number and ratio change depending on inflammatory changes in the mammary gland. The somatic cell count can change depending on the occurrence of mastitis, but also on the stage of lactation, animal age, season and other diseases of the dairy cow. Milk with an increased number of somatic cells has an altered quality compared to the milk of a healthy cow. Milk contains a lower proportion of milk fat and lactose, and an increased proportion of protein. Furthermore, electrical conductivity is increased due to elevated concentrations of chlorine and sodium in milk. It also has reduced thermal stability and a reduced ability to curdle and form lumps. Such milk has a rancid taste and is not suitable for the production of condensed milk, milk powder or sterilized milk. The shelf life of cheeses produced from such milk is reduced due to the retention of a larger amount of water. Proper and regular disinfection of udder teats before and after milking raises the yield and quality of milk, and reduces the cost associated with mastitis treatment, thereby increasing both milk quality and farm revenues. quality

Key words: mastitis; somatic cells; milk; milk 